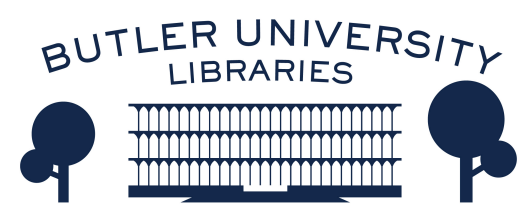

Journal of Hindu-Christian Studies

Volume 2

Article 13

January 1989

\title{
Viewpoints: The Ongoing Dialogue
}

\author{
Raimundo Panikkar
}

Follow this and additional works at: https://digitalcommons.butler.edu/jhcs

Part of the Religion Commons

\section{Recommended Citation}

Panikkar, Raimundo (1989) "Viewpoints: The Ongoing Dialogue," Journal of Hindu-Christian Studies: Vol. 2, Article 13.

Available at: https://doi.org/10.7825/2164-6279.1022

The Journal of Hindu-Christian Studies is a publication of the Society for Hindu-Christian Studies. The digital version is made available by Digital Commons @ Butler University. For questions about the Journal or the Society, please contact cbauman@butler.edu. For more information about Digital Commons @ Butler University, please contact digitalscholarship@butler.edu. 
the Gospel of Christ. Only Christ and His spirit operating through the preaching of Gospel produces the preparation and leads men to accept Christ". Christ to be relevant and to be acceptable should be presented to the Hindu as he was an Asiatic human being who lived in an Asian country and who preached a way of life easily understandable to the Asian mind.

\section{The Ongoing Dialogue * Raimundo Panikkar University of California Santa Barbara, U.S.A.}

Dialogue is more than a flippant or merely well-intentioned conversation. And the Hindu Christian Dialogue, in the present state of affairs, demands both a deep experience of one's own tradition and a sufficient knowledge of the other one. We do not begin anew. This dialogue is not of yesterday. It requires a certain knowledge of what has already happened. The history of this Encounter has a loaded karma.

Some twelve million Hindus live today in the West and their number is multiplying. Not all of them are "orthodox" Hindus. Yet the archetypes still come from the Indic traditions. An increasing number of Westerners also have close ties with the Indic subcontinent. Not all of them are "orthodox" Christians. Yet the archetypes still come from the Christian tradition. The mutual interactions are inevitable. Understanding among people belonging to those two religions is imperative for peace in the world. And the way is neither isolation nor competition but dialogue. It should be clear here that Hinduism is not reducible to orthodox versions of it. Religions today, as in times gone by, are living entities. They are moving and changing realities - labels notwithstanding. Only from the outside we have a static view of a religion. If we consciously and sincerely live a religious faith we experience at the same time the freedom to transform it precisely by living it. The Hindu Christian Dialogue of the present cannot be limited to discussing frozen doctrines of the past. And yet the past is still effective in the present. We cannot neglect it.

Dialogue, to begin with, has to be duologue. There have to be two logoi, two languages encountering each other, so as to overcome the danger of a double monologue. One has to know the language of the other, even if one has to learn it precisely from the other, and often in the same exercise of the dialogue. Dialogue engages the intellect, the logos. The academic study of religion is not a luxury.
At the same time, it has to be dia-logue i.e., a piercing of the logos, an overcoming of the mere intellectual level, a going through the intellect into an encounter of the whole person. It has to proceed from the praxis and discover the symbolic power of action.

The dialogue comes from the heart of the people, and is situated in the middle of life. The spinning wheel is the symbol of Gandhiji's challenge to technocracy and the way of saying that the Hindu Christian Dialogue has to proceed starting from both sides. Many present day dialogues set the stage according to the terms of one of the parties alone. To assume that Christocentrism, or Theocentrism can offer a basis, is as unsatisfactory as to presume that apauruseyatva, or karman are proper starting points. But there is a much more subtle danger for the fruitful and unbiased Dialogue: Modernity.

The modern kosmology (sic) assuming time is linear, history is paramount, individuality is the essence of Man (sic), democracy is an absolute, technocracy is neutral, social darwinism, and the like, cannot offer a fair platform for the Dialogue. The basis for the Dialogue cannot be the modern Western myth. As I have explained elsewhere we face here a Conflict of Kosmologies. Religions are not only doctrines. And even doctrines have roots in the respective myths which make the doctrines plausible. Modern Science has permeated to such an extent the modern world that makes it difficult not to take it as the basis of the Dialogue. Both Hinduism and Christianity have to come to grips with Modern Science, but it would not be fair to Hinduism to consider Modern Science as the neutral starting point. Modern Science is not Christianity but both share many common myths which are extraneous to the Hindu traditions. One can understand a certain Hindu resistance to an apparently neutral Dialogue based on the assumptions of a scientific kosmology.

In other words, a complete dialogos should be at the same time a diamythos. The respective logoi are bearers of meaning and life only within their respective mythoi. And it is by means of dialogue that we reach the myth of the other and create a climate of communication. The mythos belongs certainly to a prologue introducing the dialogue. The mythos is that which goes before the logos and makes it possible. The pro-logue, the foreword belongs to the mythos, the Unsaid because it is taken for granted. . .

How often have academics forgotten, if not despised, the spinning wheel! How often communal riots and cold wars have persisted through the ages because people have forgotten, if not despised, to learn the language of the other! Language here means, of course, more than Hindi and spinning wheel, more than khadi.

$$
\text { * * * }
$$

Kerala Christians, Francis Xavier, Akbar, British Raj, Hindu Renaissance and present day situations are described as the necessary background for what I have called the fourth phase of the Hindu Christian Dialogue.

The first phase could be described as the period in which Hindus were the dominating power. All too often the history of Kerala Christians has been judged from the perspective of the second phase. The second phase is that in which Christians had the power, although they were not the majority. All too often, also, the Hindu reactions to an overwhelming Christian domination has not been sufficiently underlined.

I am saying that the Hindu Christian Dialogue has never been a round table conference, nor a merely theoretical exercise in brahmodya. It is embedded in particular socio-political circumstances and takes place within a certain elusive myth.

The first phase was that of a tiny minority finding its own identity: Christians dialoguing with the Hindu majority in order to establish their own identity. No wonder that the dialogue was not one of great theological speculations, as it has been noted. It is the Christian dialogue with Hinduism.

The second phase re-inverses the roles. Demographically the Hindus were majority, of course, but the power was on the other side. Hinduism had to establish its identity, and awaken from an alleged slumber which had permitted, first the Muslim, and later the Christian conquests. The so-called Hindu renaissance is witness thereof. It is a Hindu dialogue with Christianity.

The third phase is the prevalent one today in religious and academic circles. It could only flourish after the colonial period. It is the Hindu-Christian Dialogue. Christians, to be sure, have taken most of the initiative, and it has been a predominantly Christian-Hindu Dialogue, but Hindu voices are also present and many of the Christians have adopted an unpartisan stance. It has been a predominantly doctrinal dialogue. Christian doctrines have been deepened, enlarged or perhaps also thinned for the sake of the Dialogue. Hindu doctrines have been awakened so as to show that there was also "science", "rationality", service of the neighbour, and the like in the Hindu lore. Comparative 
studies of great value have appeared. Shankara and Aquinas, Krishna and Christ, Hindu and Christian pilgrimages, the notion of Grace, Scriptures, God, etc. are today well-studied topics. But comparative studies are only implicit dialogues.

The fourth phase, I submit, challenges the fixed identity of both parties. The fecundation of the previous phases produces its effects. The fourth phase is a genuine Dialogue among people who happen to be Hindus and Christians. It is the religious Dialogue among Hindus and Christians.

The fourth phase starts a dialogue in which neither a politically dominating Hinduism nor an established and powerful Christianity have the upper hand or offer the frame in which the dialogue takes place. Nor is the dialogue purely dialectical or simply doctrinal. The dialogue has gone deeper, on the one hand, and more external, on the other. Deeper, for we discuss personal issues and beliefs with immense consequences for our lives. More external, in that we do not coinvolve large communities or speak from the definite angle of a church or sampradaya. Both sides seem to be confronted with a similar technocratic civilization, even in the remote corners of the country-side.

It would amount to take a superficial stance and possibly to a betrayal of one's deepest convictions were we to deal with modern problems of technocracy, peace, justice, hunger, or simply business, and work, making abstraction of religious beliefs or relegating them to the private sphere. But the Hindu and Christian contexts are different. The contexts are religious and personal, but at the same time they are political, economic, secular, and they inform ordinary life. Do we need a Khomeini to remind us brutally that one side alone does not set the rules of the game? The fourth phase of the dialogue is a burning issue. The quick rise of an Indian middle class apparently successful in the rules of a competitive society in a technocratic set up is not an alien problem of the Hindu Christian Dialogue. It becomes a necessary dialogue-perhaps for survival.

It is, first of all dialogue. It is a dialogue between experts or common people, merchants or industrialists, intellectuals or artists which happen to more or less love their traditions, but who are not tied to them to such an extent so as to defend any fixed orthodoxy. The archetypes may play a more important role than the explicit ideas. To be sure, any authentic dialogue is a search for truth, and incurs thus the "risk" of finding itself aiso "outside" the fold. But in this emerging fourth phase there are no non-negotiable topics, no "classified" materials or hidden agendas, not because previously people were not sincere, but because the very notion of orthodoxy has become flexible, dynamic, and not merely intellectual.

It would be a set back in the dialogue if this fourth phase were to fall into the temptation of superficiality.

The fourth phase is a new step. It is creative not only in interpreting the "other". It is also innovative in understanding "oneself".

I could put it in terms of depth psychology. A Christian, after twenty years of studying Hinduism, a Hindu, after a similar period of struggling with Christians, should they not assume that in an imperceptible way the studied subject matter has made inroads in the psyche of the Christian or the Hindu - just as one spontaneously imitates the gestures and idioms of the persons one lives with? Should we not suspect also that you may one day fall in love with the person with whom you are constantly dealing? Cultural symbiosis is also a phenomenon happening among religious traditions.

*Excerpts from Preface to forthcoming book: Hindu-Christian Dialogue edited by Harold Coward. Maryknoll: Orbis Books, 1989 (Fall).

\section{NEWS}

\section{New Publication}

Hindu-Christian Dialogue, edited by Harold Coward will be published by Orbis Books in the Fall of 1989, in its "Faith Meets Faith" Series. The ISBN number is 0-88344-633-2, $\$ 13.95$ (paper); 0-88344$634-0, \$ 26.95$ (cloth). The book is a State of the Art review of Hindu-Christian Dialogue from its beginnings to the present. Chapters are written by Anand Amaladass, Ronald Neufeldt, Roland Miller, Richard Young, John Webster, Eric Sharpe, Richard Taylor, David Goa, Steven Gelberg, A. Frank Thompson, Paul Younger, Murray Rogers, Anantanand Rambachan, Robert Baird, Harold Coward, S. Wesley Ariarajah, and Klaus Klostermaier, with a Preface by Raimundo Panikkar.

\section{"Christ and Krishna" Reissued}

The book Christ and Krishna by Swami Bhaktipada, first published in 1985, has been reissued with an Introduction by the Christian theologian Harvey Cox of Harvard University. Cox recounts his visit to Vrindaban and his Christian response to finding himself among the narrow streets filled with pilgrims singing and dancing their praises to Krishna. Cox comments, "I had felt close to God throughout all of this, without for a moment sensing any distance from the Lord Jesus or from the God I know and love in Him." (p. iv) This experience prompts Cox to ask the question, "Christ and Krishna. Krishna and Christ. What do these figuresperhaps the two most widely known and admired personalities in world historyhave to do with each other?" (p. iv) Cox suggests that this question is a modern day counterpart of the much earlier question "What has Athens to do with Jerusalem?" Theological responses to the AthensJerusalem question, suggests Cox, provide a precedent for conciliatory thinking on the contemporary question "What has Nazareth to do with Vrindaban?" The latter question, however, Cox finds to be more complex.

Cox is particularly attracted by the fact that in a world filled with hatred and division, Krishna's message is for love and reconciliation. This resonates strongly with the central Christian teaching "God is Love." He suggests that the messages of the Bhagavad-Gita and Jesus' Sermon on the Mount transcend religious boundaries. His experience of God in Jesus Christ, says Cox, was "enriched by the Divine Spirit I felt in Vrindaban, and I am surer than I am of most things that that Spirit is the same One who came to dwell among us in a stable and died on a cross to conquer death." (p. viii)

(Christ and Krishna by Swami Bhaktipada, 2nd Edition. New Vrindaban, Moundsville, W. Va.: Bhaktipada Books, 1987. ISBN 0-933215-03-3)

\section{Rethinking Christianity in the Indian Context}

The Christian Study Centre for Culture and Social Change of the Kerala University, Trivandrum, organised a oneday seminar on "Rethinking Christianity in the Context of Indian Philosophy and Religions", on 17, March 1989. There were about a hundred participants from various walks of life. The keynote paper was presented by Prof. Dr. John Arapura of the Department of Religious Studies at McMaster University, Hamilton, Canada.

As Dr. Arapura explained the theme, it is not a call for indegenisation, but it is an attempt of self-understanding on the part of. Christianity in its existence in the unique world of Indian Philosophy and Religions. Such self-understanding must lead to a revolution in Christianity's mode of being and self-expression in India, with undoubted effect upon Christianity globally. 